УДК 37.013.21

\title{
ТРАНСФОРМАЦИЯ ДУХОВНЫХ ЦЕННОСТЕЙ В УСЛОВИЯХ СОВРЕМЕННОЙ ЦИВИЛИЗАЦИИ
}

\author{
Полотнянко Василий Сергеевич \\ Тедеева Людмила Николаевна \\ преподаватель
}

ФГБОУ ВО «Волгоградский государственный аграрный университет»

\begin{abstract}
Аннотация: В данной статье рассматриваются проблемы трансформации духовных ценностей современного общества. Социокультурная реальность констатирует изменения духовной сферы общества в сторону обесценения природных основ человеческой жизни в психологии человека, в механизмах социализации, образе жизни и приемах общения. Главным духовным ресурсом человеческой жизнедеятельности в постиндустриальной эпохе становится информационность, а виртуальная реальность трансформирует естественные формы бытия. Виртуальная коммуникация формирует новые идеальные формы восприятия мира и переосмысления концепции человека в общественном сознании. В нынешних условиях жизни произошла культурная трансформация ценностей, которая обуславливает риск социальной незащищённости человека.
\end{abstract}

Ключевые слова: информационное общество, посиндустриальная эпоха, гуманизм, общественное сознание, социокультурная реальность, бытие, «вторая природа», социальные риски, социальный институт, социальное самочувствие, социальный ресурс, социальная идентификация.

\section{TRANSFORMATION OF SPIRITUAL VALUES IN THE CONDITIONS OF MODERN CIVILIZATION}

\section{Polotnyanko Vasily Sergeevich Tedeeva Lyudmila Nikolaevna}

\begin{abstract}
This article deals with the problems of transformation of spiritual values of modern society. Sociocultural reality States changes in the spiritual sphere of society in the direction of devaluation of the natural foundations of human life in
\end{abstract}


human psychology, in the mechanisms of socialization, lifestyle and communication techniques. The main spiritual resource of human life in the post-industrial era is information, and virtual reality transforms the natural forms of being. Virtual communication forms new ideal forms of perception of the world and reinterpretation of the concept of a person in the public consciousness. In the current conditions of life, there has been a cultural transformation of values, which causes the risk of social insecurity.

Key words: information society, post-industrial era, humanism, social consciousness, socio-cultural reality, being, "second nature", social risks, social institution, social well-being, social resource, social identification.

Культура информационного общества опутало человечество глобальной социальной «паутиной», формируя специфические условия развития сознания, которое строится не только на восприятии реального мира, но и за его пределами. Культурное сознание переживает глубокий кризис, происходит трансформация культурных ценностей, среда обитания человека приобретает рискогенные признаки. Человечество стремительно утрачивает культурное сознание в традиционном, национально-этническом смысле.

Огромный поток информации, в том числе и ненужной информации, приводит к утере самостоятельности духовной жизни человека. Несмотря на индивидуальный характер духовных ценностей, их своеобразие и неповторимость, общепризнанные ценности (доброта, честность, воспитанность, трудолюбие, человечность, терпимость, порядочность) охватывают не одну сферу той или иной деятельности человека. Трансформация духовных ценностей приводит к негативным процессам в различных сферах жизни социума, в этой связи возрастает актуальность исследования данной проблемы.

Цель исследования проблемы трансформации духовных ценностей предполагает показать изменение фундаментальных оснований человеческого бытия, показать культурную обусловленность влияния «второй природы» человека в его преобразовательной деятельности. «Вторая природа» - это созданная человеком реальность», которая характеризуется как искусственная, специальная, неприродная...» [3, с. 93]. Необходим пересмотр отношения к природе, к идеалам социального мира, нужна выработка нового понимания перспектив человека, как природного естественного существа. 
Проблема духовных ценностей берет свое начало еще в работах Г. Гегеля, М. Вебера, Г. Спенсера, Э. Дюркгейма. Социально-философская концепция духовно-нравственной жизнедеятельности общества описана в марксистском подходе. Разработка актуальных проблем духовнонравственной жизни в социальной философии и социологии представлена в работах М.С. Кагана, Л.Н. Когана, Ф.И. Минюшева. Теоретикометодологическим основанием философского анализа духовно-нравственных ценностей различных социальных групп, представляется в разработке концепции социального развития молодежи, в которой описывается обоснование ее субъектности духовной жизни (В.И Чупров). Анализ разных взглядов духовно-нравственных приоритетов молодежи дается в теориях: социального самоопределения (В.Т. Лисовский, С.Н. Иконникова), социоструктурных изменений (В.И. Староверов), образовательных стратегий (В.И. Добрынина, Т.В. Ковалева, Т.Э. Петрова), социализации (А.А Щегорцов, А.И. Ковалева), гражданских идентификаций (Е.А. Гришина, А.А. Козлов).

Современное общество, характеризующееся состоянием кризиса во всех общественных подсистемах. В контексте такого социокультурного положения, происходит переоценка ценностей и резкая смена идеалов. Приоритетными давно стали - материальное благосостояние, личное благополучие, карьерный рост. «Несомненно, ценностные категории и понятия, выражая структурные отношения индивида и общности, закрепляют и определенное ценностное отношение, поскольку ценностная регуляция дает возможность связывать интересы отдельных индивидов с потребностями системы, образуемой той общностью людей, в которую эти индивиды включены» [6, с. 94].

Обратимся к определению понятия «ценность». Ценность - это «сложившаяся в условиях цивилизации и непосредственно переживаемая людьми форма их отношения к общезначимым образцам культуры и к тем предельным возможностям, от осознания которых зависит способность каждого индивида проектировать будущее, оценивать «иное» и сохранять в памяти прошлое» [2, с. 88]. Однако, содержание понятия «ценность» меняется в процессе социального и культурного развития, так как меняется характер отношения человека к окружающему мирозданию. В различных исторических эпохах по-разному трактуется понимание сущности ценности.

«Деструктивные процессы в духовной жизни современного социума создают угрозу жизнеспособности государства в целом. Обозначенное 
явление выступает катализатором трансформации индивидуальной и общественной морали, выраженной в росте аморальности, правового нигилизма. Для борьбы с этим явлением необходимо создание и реализация матрицы духовных ценностей» [9, с. 88].

Многие исследования процессов социализации личности убедительно показывают тот факт, что культурное наследие, традиции, обычаи, существующие нормы и правила рано или поздно сталкиваются в сознании индивида с альтернативной реальностью. В конце первого десятилетия XXI в. социальные сети обеспечили так называемую «шоковую» модернизацию традиционных обществ, для которых культурное достояние стремительно утратило свое значение. «Современному человеку грозит полное духовное истощение, он испорчен комфортом и изобилием....» [1, с. 306].

Когда в тот или иной исторический период какие-либо из таких ценностей как: доброта, честность, воспитанность, трудолюбие, человечность, терпимость, порядочность перестают быть значимыми, необходимо вмешательство государства или общественных организаций - неотъемлемых составляющих развитого гражданского общества и демократии.

Для того чтобы определить, какие общечеловеческие ценности стабильны, какие уходят в прошлое, а какие формируются - необходимо учитывать совокупность факторов, влияющих на данные процессы. Динамика ценностей прослеживается на уровне социальных институтов семьи, культуры и образования. «В условиях культурной трансформации ценностей нарушается не только социальная идентификация, но и самоидентификация, что приводит к уязвимости незащищённости социального субъекта» [7, c. 127].

Положительный результат можно достичь лишь при сочетании теории и практики, содержания гуманитарных наук с данными, полученными эмпирическим путем. Только в человеческом мире есть недостатки: «именно то, чего нет, определяет то, что есть» [5, с. 70].

Исследуя процесс трансформации духовных ценностей, протекающий среди различных возрастных групп населения, можно выделить то, что приоритетными выступают ценностные установки на высокий уровень жизни. Ф. Ницше указывает на то, что «человек находится в духовном регрессе. Выполняя моральные нормы, он находится во лжи с самим сбой» [4, с. 172].

В условиях формирования новой системы ценностных ориентаций, важно ориентироваться не только на активную гражданскую позицию и чувство долга, а на универсальный критерий истинности человеческого бытия 
- гуманизм. «Необходимо также руководствоваться принципом самоценности человеческой личности, что будет способствовать ослаблению антагонистических процессов в социуме» [8, с. 389].

Важной и общей задачей на сегодня является выведение общества из состояния ценностного и духовного коллапса. Большая часть негативных характеристик общественной жизни проявляются в самом труднопреодолимом кризисе - кризисе духовных ценностей. Людям придётся научиться определять границы реальности в осознании собственной биологической природы, научиться осознавать риски человеческой жизни и, наконец, понять её ценность в условиях конечности человеческого бытия. Осмысление механизмов проявления человеческого в человеке и прогнозирование закономерностей поведения в реальном времени жизни станут условием успешного преодоления духовного кризиса и положительного социального самочувствия людей.

\section{Список литературы}

1. Гуревич, П.С. Основы философии. Учеб. Пособие./ П.С.Гуревич. Москва: Гардарики, 2000. - 438 с.

2. Кемерова В.Е. Современный философский словарь. М.: Академический проект, 2004. - 864 с.

3. Ладухина М. В. Культура как «вторая природа»: опыт культурологического анализа: автореф. ... канд. культурологии: 24.00.01. М., 2005. - $161 \mathrm{c}$.

4. Ницше Ф. Воля к власти. Опыт переоценки всех ценностей. М.: Культурная Революция, 2005. - 880 с.

5. Сартр Ж.-П. Бытие и ничто: опыт феноменологической онтологии; пер. М.: Республика, 2000. - 639 с.

6. Столович Л.Н. Об общечеловеческих ценностях // Вопросы философии. 2004. - № 7. - С. 86-97.

7. Тедеева Л.Н. Культурная обусловленность трансформации ценностей и социальные риски. // Оптимизация сельскохозяйственного землепользования и усиление экспортного потенциала АПК РФ на основе конвергентных технологий: материалы Международной научнопрактического форума. Волгоград, 2020. Т 6. - С. 125-129

8. Янгузин А.Р. Аспекты матрицы духовных ценностей // Евразийский юридический журнал. - 2017. - №4 (107). - С. 388-389

9. Янгузин А.Р., 2017, Философские науки // KANT. - 2017. - №3(24). C. $88-92$

(C) В.С. Полотнянко, Л.Н. Тедеева, 2020 